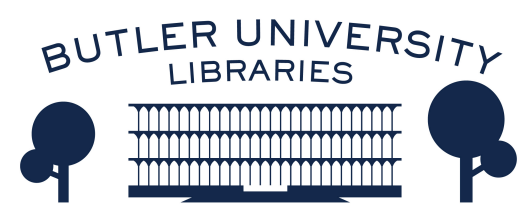

Journal of Hindu-Christian Studies

Volume 2

Article 11

January 1989

\title{
Viewpoints: The Value of Inter-Faith Dialogue
}

L. Sundaram

Follow this and additional works at: https://digitalcommons.butler.edu/jhcs

Part of the Religion Commons

\section{Recommended Citation}

Sundaram, L. (1989) "Viewpoints: The Value of Inter-Faith Dialogue," Journal of Hindu-Christian Studies: Vol. 2, Article 11.

Available at: https://doi.org/10.7825/2164-6279.1020

The Journal of Hindu-Christian Studies is a publication of the Society for Hindu-Christian Studies. The digital version is made available by Digital Commons @ Butler University. For questions about the Journal or the Society, please contact cbauman@butler.edu. For more information about Digital Commons @ Butler University, please contact digitalscholarship@butler.edu. 
native views emerging for instance in the recent writings of leading physicists and psycho-analysts of the West who suggested to overcome the binary opposition of "clarity of Greek autonomous thinking" vs. "befogged mythic superstitions of the Orient" are discarded by Halbfass as "syndrom". Halbfass seems to be encapsuled in a form of thinking built upon ancient assumptions of irreconcilable oppositions structured in a hierarchical fashion. Such attitude precludes a more inspiring and holistic vision of interwovenness and interdependence of systems of thought originating from different cultural contexts. Thus the conservative thinking of the author leads to the conclusion that because of the Europeanization of the earth "ancient Indian thought, in its unassimilable, non-actulizable, yet intensely meaningful distance and otherness, is not obsolete." If that were true then the meaningfulness of Indian thought serves the sole purpose of re-affirming the Occident as "subject" and cementing India in the role of the "other" in distant "objectification", thus excluding it from the dynamic and live context of human existence in all its cultural diversity. Such thinking continues the marginalization of non-European civilizations, thereby increasing the already existing gap between the "West" and the "rest of the world".

This critique should however not obscure the fact that, if the reader is comfortable with Halbfass' conservative methodological approach, the book is a comprehensive description of the mutual perceptions of India and Europe as developed up to the 20 th century. Whether it constitutes "an essay in understanding" as the title promised needs to be questioned.
Eva Dargyay
University of Calgary
Calgary, Canada

\section{VIEWPOINTS}

\section{The Value of Inter-Faith Dialogue L. Sundaram, S.J. \\ Loyola College, Madras, India}

The purpose of inter-faith dialogue is evidently not to arrive at or achieve a common set of beliefs giving up for the sake of unity one's own religion's cherished doctrines. Its aim is not to accomplish a merger, as of two political parties or groups, nor to arrive at the lowest measure of agreement in religious beliefs. If the participants in a dialogue are only "light half-believers in a casual creed who never deeply loved or deeply felt" their dialogue will remain at only a superficial level. The paradox therefore in such meetings, is that those who dialogue must be persons of deep conviction and personal commitment to their faith and yet are eager to keep their minds open to beliefs and traditions other than their own, ready to learn from them and to fill up gaps in their own religious experience and knowledge. It is obvious therefore that it is wrong to expect short-term "results" from the dialogue process. In this world of division at every level of life and particularly at the level of religion it is first of all necessary to bring people together of different persuasions and strong convictions. It is necessary not only to speak about the Fatherhood of God and the brotherhood of man but in fact act our belief in all our interpersonal relationships at every level of life especially the religious level. When at this level we truly begin to deal with all our brothers and sisters as equally with us children of the same Father, then and only then genuine dialogue can begin.

I make these reflections in the light of some experience of inter-faith dialogue over the years. It is true that not all participants in a dialogue necessarily come with an open mind. Often they attend the dialogue meetings more or less under moral pressure from friends or some times also in a spirit of ordinary intellectual curiosity to see what it is all about. But if one meeting leads to another and they continue to come, then things begin to happen however slowly but surely. The very fact that every dialogue begins with a few moments of (silent or vocal) prayer makes one realise that in prayer made together somehow a spirit of union of hearts is born often imperceptibly. And God's grace begins to build on that. For nothing is more certain than this: that God's salvific will regarding his children is universal. St. Peter after integrating Cornelius the Roman Centurion into the Christian Community "opened his mouth and said: Truly I perceive that God shows no partiality, but in every nation any one who fears Him and does what is right, is acceptable to Him." (Acts 10, 34-5)

The perception of God's will however is not the same in every individual nor the awareness of "what is right". Hence different views on the objectivity of religious truth. Even the voice of conscience, Kant's "categorical imperative" does not speak in the same manner or with the same effectiveness in every human heart. Many are the barriers to hearing "the still small voice; erected by environment, in-built traditional attitudes in the human consciousness, cultivated prejudices, weakness of the will to follow the light of the intellect. Intellectual conviction about what is the will of God does not necessarily imply the conversion of the personal will to $\mathrm{Him}$ and $\mathrm{His}$ behest. And there is also the problem of varieties of religious experience which often run only on parallel lines. Advaitins claim that the experience of oneness with the Eternal Brahman is the ultimate truth: every other experience only leads to the realisation of this non-duality. A rapid view of different religions and convictions makes one almost fall into despair: will it ever be possible to reach unity? The disparities and differences seem to be so great that genuine union looks impossible of achievement.

And yet there is in all of us an irrepressible longing to come together. There is in people of all religions today a deep desire to understand one another and to realise not only notionally but in daily life and practice that whatever be the differences that divide and disrupt the human family, we must act towards one another as brothers and sisters and make an effort to analyse our differences and narrow the areas of dissent. That very effort, when sincerely undertaken, produces a climate of goodwill which is the basic disposition for all attempt at dialogue.

As member of a dialogue group at Tiruchy from its very beginnings $I$ have seen significant changes in attitudes coming over us. There were Muslims and Hindus, Christians of different denominations and at least one who called himself an agnostic and atheist. We used to begin with moments of silence and some oral and vocal prayer or bhajan. When sharp differences in belief came to the surface, explanations were asked for and given. We discovered that often we meant the same thing using different terms. A certain climate of mutual understanding began to grow. Long established prejudices and inhibitions began slowly to be corroded. And thus gradually a fellowship started to grow. Dialogue groups of this kind can be legitimately described as oases in a desert of mutual unspoken misunderstandings. They are the beginning of a deeper communication at a truly religious level at which common prayer is possible. And the rest is in the hands of God whose will is that all His children should recognize their common roots.

There was recently a debate in the Indian Express in the form of letters to the Editor on the question of some Christian leaders adopting Hindu symbols and forms of ritual for conveying the Christian message, an attempt at what has come to be called "inculturation". I shall quote from two of the correspondents who put this question of inculturation in the larger context of Hindu-Christian Dialogue. 
Professor K. Swaminathan wrote: Like Swami Vivekananda, Gandhiji, Ramana Maharishi and the Paramacharya of Kanchi, earnest Christian leaders like Dom Bede Griffiths and Swami Abishiktananda are trying to make all believers in a Higher Power understand, experience and practise their mother-religions better and more fruitfully. In this endeavour Christians here try to communicate the eternal message of Jesus through symbols and modes of worship familiar to Indians. Dom Bede Griffiths also participating in the debate wrote: "There are many different religions in India and many different sects in Hinduism, each with their own distinctive ritual and doctrine, yet sharing a common cultural tradition. It is hoped that by sharing in this common cultural tradition the Christian Churches also may be able to enter the mainstream of Indian Life, bearing their own distinctive witness to the truth, and working together with other religious communities for the good of the country as a whole. It is an urgent need that the different religions of the world should learn to co-operate with one another and not to be a source of division and conflict, as is so often the case. This seems the only way forward for humanity today".

Dialogue then, is a means of achieving inter-religious peace and understanding which is a great need of the world today, not the peace of mere coexistence, not the negative peace of non-alignment but a positive step towards accomplishing God's will for all men of every race and clime and culture. It is not easy: it often does stop at platitudes and generalisations which may be a cover for intellectual cowardice. But positively it reflects the great hunger and thirst of all peoples for establishing a world community in which all forms of injustice can be conquered, suspicions removed, and mutual respect leading to real love, can flourish.

\section{Why Dialogue With Hindus? Gladys Ambat Madras, India}

The Christians of India like the Christians all over the world are a minority amidst "the nations" or peoples other than Christians. Christians in India have the unique privilege of living with a very God conscious people - the Hindus. One cannot help but admire the simple piety of the millions who recently went for a holy dip to Varanasi. The faith, the sincerity and the utter devotion of the devotees are often beyond the understanding of those who believe that a true devotee should express his faith differently, the way Jesus said,
"God is a spirit and they that worship Him must worship Him in spirit and in truth." Symbolic rituals to such devotees are unnecessary and superfluous. Yet a close and in-depth study of Hinduism and Christianity however soon reveals that Christianity is in no way alien to Indian philosophy but a fulfilment or a simpler revelation of sublime Hindu thought and ideals. The elevation of the masses and the recognition of all people as brothers are basic and fundamental to the Christian faith. When the Secular Government and Hindu philosophers speak of these concepts, that they are the reconciling influence of Christianity sown in India, centuries ago, is forgotten. It is therefore essential that there is dialogue between the peoples of the religions of India, to understand each other, to respect each other and to learn from each other.

A pioneer of Hindu Reform movement Raja Ram Mohan Roy found that his religion, the most tolerant of all religions sadly lacked the great virtue of love for one's neighbour. He wrote "The consequence of my long and uninterrupted search into religious truth has been that I found the doctrines of Christ more conducive to inculcate moral principles and better adapted to rational beings than any other that has come to my knowledge". Mahatma Gandhi called "Jesus" the Prince of all Satyagrahis. Few who have read the works of Rabindranath Tagore can fail to see his profound and lofty faith, so akin to Christian thought, and embracing all humanity.

To transform Christian attitudes and to teach followers of Christianity humility and understanding of Hinduism, a greater insight into the sublime heights reached by those stalwarts of Hindu faith is absolutely necessary. The Hindu concept of renunciation of submission, of poverty and austerity is very much a part of the way of life taught and lived by Jesus himself. How different is the life and lifestyle of the princes and leaders of the Christian Church today! The Son of Man had no place to lay His head!

It is only through dialogue and comparative study that the Hindu and the Christian can understand each other's faith. The Christian faith has to be divested of the Western trappings for the Hindu to understand the indepth philosophy of Christianity. This is the reason why the Church today is keen on intercultural liturgies and forms of worship understandable to our Hindu brethren. "Indianising" of Christianity is often looked at doubtfully by many Christians and Hindus alike. The former considers Indianisation as diluting of the faith itself or compromising, and the latter as a way of proselytising or subtle evangelism. Dialogue is the only way the members of the two faiths can comfortably live with each other in sympathy and harmony and most of all with tolerance of each other's beliefs and faith.

Archbishop Simon Pimento of Bombay in his inaugural address at the Catholic Bishops Conference, put forward very strongly the need for inculturation. He said, "for as long as the people of India do not feel Christianity as part of their own flesh and blood, their own soul (and they do not, even after centuries of the Churches presence in the country) they will not be disposed to accept it. Hence the integration of faith and culture in its complexity and variety is a great challenge to us in India."

Outstanding Christians like De Nobili and C.F. Andrews saw the need of more than dialogue. It was their deep understanding of the need for accepting the culture of the people of India which made them acceptable, honoured and revered by the Hindu millions who knew themGopal Krishna Gokale founded the Servants of Indian Society on the lines of the Society of Jesus and the Mahatma conducted a Bible Study Course in the Gujarat National College - thus accepting from another faith, that which is its essence is true acceptance and more valuable to the human soul than just dialogue.

Few Christians can explain the profound significance of the last Supper as did Keshab Chandra Sen, a Hindu of the 19th Century. Jesus said; "He that eats my flesh and drinks my blood dwells in me and I in him". To many this sentence sounds absurd. Several people including Christians have talked of the Mass and the Holy Communion as a cannibalistic ritual. K.C. Sen's understanding is truly sublime, (not only profound, but the most logical). He writes "How could men eat Christ and drink his blood? This was possible in one sense only. In the sense of spiritual identification. That indeed is Christ's mission. He wanted his followers to eat him and assimilate him to their hearts and incorporate him into their very being."

Jesus Christ said "I have not come to destroy but to fulfill" - Therefore from the point of view of the Christian, in order to stress the common humanity of the Community of Man, and because Jesus came to bring peace and goodwill to all mankind, dialogue with those of other faiths is very important and should be very much a part of the programme and mission of the Church. However, as M.M. Thomas says "No Religion or culture could prepare man for an acceptance of 